\title{
Особливості зміни видового складу мікрофлори при застосуванні вакуумної терапії хронічних ран у хворих на синдром стопи діабетика
}

\begin{abstract}
Мета роботи: вивчити зміну кількісного та якісного складу мікрофлори при застосуванні вакуумної терапії хронічних ран у хворих на синдром стопи діабетика.

Матеріали і методи. На основі обстеження та лікування 122 хворих на цукровий діабет, ускладнений синдромом стопи діабетика, які впродовж 2013-2016 рр. перебували на стаціонарному лікуванні в клініці загальної хірургії ДВНЗ “Тернопільський державний медичний університет імені I. Я. Горбачевського МОЗ України” (Тернопільської міської комунальної лікарні швидкої допомоги). Серед обстежених хворих чоловіків було 79 (64,8 \%), жінок - 43 (35,2 \%) віком від 47 до 69 років. Хворих на ЦД легкого ступеня було 19, середньої тяжкості - 76, тяжкого - 27. Стадію компенсації ЦД діагностовано у 43 хворих (35,2 \%), субкомпенсації - у 62 (50,8 \%), декомпенсації - у 17 (14 \%) пацієнтів. Хворих із невропатично-інфікованою формою (НІФ) ССД було 48 (39,3 \%), ішемічно-гангренозною (ІГФ) - 74 (60,7 \%). Всім хворим проводили загальне клініколабораторне та інструментальне обстеження: об'єктивне обстеження, збір скарг та анамнезу захворювання, вивчали зміни мікрогемодинаміки нижніх кінцівок, проводили цитологічні, мікробіологічні та морфологічні дослідження. Терапевтичний вплив вакууму забезпечували за допомогою вакуум-апарата “АГАТ-ДНІПРО” (80-125 мм рт. ст.). Кількісний та якісний склад мікрофлори визначали за допомогою бактеріологічного дослідженням ранового ексудату на день госпіталізації, 3, 6, 9 та 14 доби лікування.

Результати досліджень та їх обговорення. Мікробіологічне дослідження показало, що у 42,6 \% спостерігалося поєднання 2-3 видів мікроорганізмів, у 57,4 \% - 4-5. Частіше при хронічних ранах висівалася грампозитивна мікрофлора (62,48 \%). Порівняно з госпіталізацією, достовірно зменшувалася колонізація ранових дефектів (р<0,05-0,01). Таку ж тенденцію спостерігали

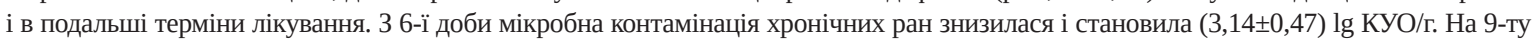
добу загальна кількість мікроорганізмів становила $(3,36 \pm 0,37) \lg$ КУО/г в контрольній групі проти $(1,94 \pm 0,12) \lg$ КУО/г в основній групі, а з 14 дня лікування з ран не виділялися лише аеробні бацили. Доведено, що застосування вакууму для лікування хронічних ран зменшує кількісний та видовий склад мікроорганізмів, що, в свою чергу, дозволяє скоротити стаціонарне лікування хворих у середньому на $(4,1 \pm 1,7)$ ліжко-дні.
\end{abstract}

Ключові слова: цукровий діабет; синдром стопи діабетика; вакуумна терапія.

Постановка проблеми і аналіз останніх досліджень та публікацій. На сьогодні у світі цукровий діабет (ЦД) - найбільш поширене хронічне захворювання серед неінфекційних хвороб, яке становить понад 70 \% у структурі всієї ендокринної патології $[1-3,8]$. Менш ніж за 20 років число хворих на ЦД у світі збільшилося в 6 разів, продовжуючи подвоюватися кожні $12-15$ років [2-4, 6]. У 70-80 \% хворих на ЦД зустрічаються ускладнення у вигляді мікро- і макроангіопатій, нефропатій, які лежать в основі патогенетичних механізмів формування синдрому стопи діабетика (ССД). Ускладнені форми ССД супроводжуються утворенням хронічних відкритих ранових дефектів у вигляді трофічних виразок та післяопераційних ран, які характеризуються високою контамінацією та широким спектром мікроорганізмів. Це значною мірою впливає на перебіг фаз ранового процесу та тактику комплексного лікування [1, 4, 5,7].

Це зумовлює необхідність використання диференційованих комплексних підходів до патогенетичної терапії ССД. Однією із новітніх методик місцевого лікування ран є вакуум-терапія, позитивний вплив якої на рановий процес полягає у сприятливому впливу на перебіг ранового процесу, зменшенні кількості етапних некректомій, у скороченні термінів підготовки ран до автодермопластики та ін. [2, 5]. Однак вплив вакуум-терапії на зміну кількісного та видового складу мікрофлори хронічних ранових поверхонь у хворих 3 синдромом стопи діабетика вивчено недостатньо, а тому вимагає подальших досліджень.

Мета роботи: вивчити вплив вакуумної терапії на мікрофлору хронічних ран у хворих на синдром стопи діабетика.

Матеріали і методи. Робота грунтується на матеріалах комплексного обстеження та лікування 122 хворих на ускладнені форми ССД, які впродовж 2013-2016 рр. перебували на стаціонарному лікуванні в клініці загальної хірургії ДВНЗ “Тернопільський державний медичний університет імені І. Я. Горбачевського МОЗ України” (хірургічне відділення Тернопільської міської комунальної лікарні швидкої допомоги). У всіх пацієнтів було отримано інформовану згоду на запропоновані дослідження та методи лікування. Серед обстежених хворих чоловіків було 79 (64,8 \%), жінок 
- 43 (35,2 \%) віком від 47 до 69 років. Середній вік пацієнтів склав $(62,7 \pm 4,5)$ року. Хворих на ЦД легкого ступеня було 19, середньої тяжкості - 76, тяжкого - 27. Тривалість захворювання коливалась в межах від 8 до 35 років і в середньому складала $(12,8 \pm 4,2)$ року. Стадію компенсації ЦД при госпіталізації діагностовано у 43 хворих (35,2 \%), субкомпенсації - у 62 (50,8 \%), декомпенсації - у 17 (14\%) пацієнтів. Хворих із невропатично-інфікованою формою (НІФ) СДС було 48 (39,3 \%), ішемічно-гангренозною (ІГФ) - 74 (60,7 \%). За глибиною ураження хворих із І ст. було 15 (12,3 \%), II ст. - 26 (21,3 \%), III ст. - 58 (47,4 \%), IV ст. - 23 (19\%) (за Мегіт-Вагнером). Хворі з хронічною артеріальною недостатністю (XАH) IV ст., $з 0$ та V ступенем участь у дослідженні не брали. Хронічними рановими дефектами вважали рани, які не гоїлися чотири тижні і більше. Хворим проводили загальне клініко-лабораторне та інструментальне обстеження, що включало: об'єктивне обстеження, збір скарг та анамнезу захворювання. Вивчали зміни мікрогемодинаміки нижніх кінцівок, проводили цитологічні, мікробіологічні та морфологічні дослідження. Отримані результати обробляли статистично відповідно значень критерія Стьюдента, за допомогою комп'ютерних програм S-PLUS 2000, STATISTICA, Excell. Результати вважали достовірними при значеннях $\mathrm{p}<0,05$. Вакуум-терапію використовували залежно від виду рани та виду хірургічної обробки. Терапевтичний вплив вакууму на ранові поверхні забезпечували за допомогою вакуум-апарата “АГАТ-ДНІПРО”, з використанням від'ємного тиску в діапазоні 80125 мм рт. ст. Для накладання вакуумних пов'язок використовували стандартні набори виробництва компанії V.A.C. GranuFoamDressing (USA). Кількісний та якісний склад мікрофлори визначали за допомогою бактеріологічного дослідженням ранового ексудату на день госпіталізації, 3, 6, 9 та 14 доби лікування.

Результати досліджень та їх обговорення. Хворим із хронічними ранами проводили хірургічну обробку ран, механічний дебридмент ран із наступним застосуванням вакуум-терапії одразу після операційного втручання (сила вакууму 5080 мм рт. ст.) або на наступний день (сила вакууму 100-120 мм рт. ст.).

Дослідження мікробного пейзажу хронічних ранових дефектів показало достатньо високий ступінь контамінації, яка коливалася в межах 6,35-9,95 lg КУО/г мікроорганізмів, 3 середні-

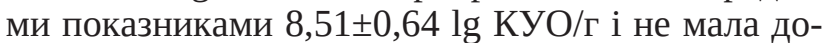
стовірної різниці відносно патогенетичної форми ССД (табл. 1).

Виділені з ран мікроорганізми належать до 6 родин, 8 родів та 38 видів, найбільшу групу мікроорганізмів склали стафілококи 3 щільністю $(9,96 \pm 0,86) \lg \mathrm{KУO/г,} \mathrm{які} \mathrm{належать} \mathrm{до} 9$ видів. Серед стафілококів домінували S. aureus (54,01\%), субдомінували - S. epidermsdis (18,48 \%), S. haemolyticus $(14,26 \%)$ та S. intermedius $(13,25 \%)$. Близько 58 \% стафілококів належали до групи коагулазопозитивних мікроорганізмів. Стрептококи в хронічних ранах зустрічалися рідко і відрізнялися найбіднішим видовим складом, хоча за щільністю мікробних угруповань займали друге місце $(9,18 \pm 0,64) \lg \mathrm{KУО/г.} 3$ хронічних ранових дефектів виділено лише три види: Str. mits, Str. equines, Str. faecalis. Наявність в рані бета-гемолітичних стрептококів $\epsilon$ передумовою незадовільних результатів лікування.

Мікрококи були представлені 5 видами: домінували $M$. varians (30,46 \%) та $M$. kristinae (25,36 \%), субдомінували - M. luteus (15,64 \%), M. lylae (15,56 \%) та M. sedentarius (12,98 \%). Видовий склад коринебактерій становив: C. afermentas (46,68 \%) - домінуючі, C. pseudotuberculosis (19,42 \%), субдомінуючі - C. pseudodiphtheriticum (16,24 \%), C. ulcerans (8,46 \%), C. xerosis (9,20 \%). Аеробні спороутворювальні бацили предствлені такими видами: B. cereus $(68,26 \%)$, B. licheniformis (18,64 \%), В. megaterium (13,10 \%). Вони склали близько 12,9 \% мікрофлори, яка виділялася з ранових дефектів у хворих, але за питомою вагою лише 2,62 \% всіх мікроорганізмів. Найбідніший видовий склад і найменша частота зустрічання була притаманна ентеробактеріям (1,46 \%) та псевдомона-

Таблиця 1. Мікробний профіль ранових дефектів у хворих на синдром стопи діабетика 3 хронічними ранами

\begin{tabular}{||l|c||}
\hline \multicolumn{1}{|c|}{ Угруповання мікроорганізмів } & Густота бактерій (lg КУО/г) (n=98) \\
\hline Стафілококи & $9,96 \pm 0,86$ \\
\hline Стрептококи & $9,18 \pm 0,64$ \\
\hline Мікрококи & $8,28 \pm 0,95$ \\
\hline Коринебактерії & $8,24 \pm 0,68$ \\
\hline Ентеробактерії і псевдомонади & $7,64 \pm 0,71$ \\
\hline Аеробні бацили & $7,13 \pm 0,64$ \\
\hline Середні показники & $8,51 \pm 0,64$ \\
\hline
\end{tabular}


дам (1,14 \%). Серед них виділені Klebsiella охуtoca, Klebsiella spp., Pseudomonas aeroginosa, та E. coli.

Мікробіологічне дослідженн асоціативних співвідношень мікроорганізмів у хронічних ранових дефектах показало, що у 42,6 \% випадків спостерігалося поєднання 2-3 мікроорганізми, у 57,4 \% - 4-5. Моноінфекція та анаеробна неклостридіальна інфекція не діагностувалися. Часті- ше при хронічних ранах висівалася грампозитивна мікрофлора (62,48 \%).

Використання вакуум-терапії дозволило встановити позитивний вплив на клінічний перебіг ранового процесу з початку 2-3 дня лікування, що проявлялося значним зменшенням густоти колонізації та видового складу мікроорганізмів в рані ( $<<0,05-0,01)$ (табл. 2).

Таблиця 2. Мікробний профіль хронічних ранових дефектів у процесі вакуумної терапії

\begin{tabular}{|c|c|c|c|c|c|}
\hline \multirow[t]{2}{*}{ Мікроорганізми } & \multicolumn{5}{|c|}{$\begin{array}{c}\text { Зміни кількості бактерій при застосуванні } \\
\text { вакуум-терапії хронічних ранових дефектів (lg KУО/г), (n=68) }\end{array}$} \\
\hline & госпіталізація & 3-тя доба & 6-та доба & 9-та доба & 14-та доба \\
\hline Ентеробактерії і псевдомонади & $7,64 \pm 0,71$ & $4,24 \pm 0,63^{*}$ & $2,68 \pm 0,54^{*}$ & $1,96 \pm 0,08 *$ & $1,21 \pm 0,05^{*}$ \\
\hline Аеробні бацили & $7,13 \pm 0,64$ & $3,34 \pm 0,28 *$ & $1,92 \pm 0,05^{*}$ & - & - \\
\hline Стафілококи & $9,96 \pm 0,86$ & $6,34 \pm 0,46^{*}$ & $4,18 \pm 0,83 *$ & $2,18 \pm 0,42 *$ & $1,94 \pm 0,15^{*}$ \\
\hline Стрептококи & $9,18 \pm 0,64$ & $6,28 \pm 0,58 *$ & $3,11 \pm 0,82 *$ & $1,48 \pm 0,09 *$ & - \\
\hline Мікрококи & $8,28 \pm 0,95$ & $6,12 \pm 0,86^{*}$ & $3,84 \pm 0,48^{*}$ & $1,62 \pm 0,08 *$ & - \\
\hline Коринебактерії & $8,24 \pm 0,68$ & $5,13 \pm 0,74 *$ & $3,21 \pm 0,43 *$ & $2,48 \pm 0,19 *$ & $1,24 \pm 0,07 *$ \\
\hline Середні значення & $8,51 \pm 0,64$ & $5,24 \pm 0,47^{*}$ & $3,14 \pm 0,47^{*}$ & $1,94 \pm 0,12 *$ & $1,46 \pm 0,08 *$ \\
\hline \multicolumn{6}{|c|}{ Контрольна група $(\mathrm{n}=30)$} \\
\hline Стафілококи & $9,88 \pm 0,72$ & $7,29 \pm 0,82 *$ & $5,43 \pm 0,46^{*}$ & $4,82 \pm 0,57 *$ & $3,14 \pm 0,35 *$ \\
\hline Стрептококи & $9,12 \pm 0,47$ & $7,68 \pm 0,64^{*}$ & $5,21 \pm 0,72 *$ & $3,76 \pm 0,24 *$ & $1,89 \pm 0,08 *$ \\
\hline Ентеробактерії і псевдомонади & $7,84 \pm 0,48$ & $6,14 \pm 0,34^{*}$ & $4,38 \pm 0,52 *$ & $2,98 \pm 0,31 *$ & $2,14 \pm 0,48^{*}$ \\
\hline Аеробні бацили & $7,18 \pm 0,53$ & $5,47 \pm 0,67 *$ & $3,65 \pm 0,62 *$ & $2,04 \pm 0,08 *$ & - \\
\hline Мікрококи & $8,36 \pm 0,68$ & $6,92 \pm 0,84^{*}$ & $5,86 \pm 0,73 *$ & $3,49 \pm 0,41^{*}$ & $2,14 \pm 0,11^{*}$ \\
\hline Коринебактерії & $8,32 \pm 0,58$ & $6,47 \pm 0,72 *$ & $4,76 \pm 0,48^{*}$ & $3,11 \pm 0,47^{*}$ & $2,67 \pm 0,25 *$ \\
\hline Середні значення & $8,34 \pm 0,58$ & $6,65 \pm 0,48^{*}$ & $4,86 \pm 0,58 *$ & $3,36 \pm 0,37 *$ & $2,39 \pm 0,28^{*}$ \\
\hline
\end{tabular}

Примітка. * - p<0,05-0,01 порівняно з даними на момент госпіталізації.

Отже, порівняно з госпіталізацією, достовірно зменшувалася колонізація ранових дефектів ( $<0,05-$ 0,01). Таку ж тенденцію спостерігали і в подальші терміни лікування. 3 6-ї доби лікування мікробна контамінація хронічних ран знизилася нижче критичних показників і становила $(3,14 \pm 0,47) \lg \mathrm{KУО/г.}$ У подальшому кількість мікроорганізмів ранових дефектів продовжувала знижуватися. 39 дня лікування з ран не виділялися аеробні бацили, а з 14 - стрептококи та мікрококи. В контрольній групі зниження мікробної контамінації ран відбувалося значно повільніше, ніж у основній групі $(\mathrm{p}<0,05)$.

На 9-ту добу загальна кількість мікроорганізмів впала нижче критичних величин і становила $(3,36 \pm 0,37) \lg \mathrm{KУO/Г} \mathrm{в} \mathrm{контрольній} \mathrm{групі} \mathrm{проти}$ $(1,94 \pm 0,12)) \lg$ КУО/г в основній групі, а з 14-ї доби лікування з ран не виділялися лише аеробні бацили.

Отже, результати досліджень підтверджують позитивний вплив вакуум-терапії хронічних ран у хворих на ССД, що сприяє в короткий проміжок зменшити кількісний та видовий склад мікроорганізмів в ранових дефектах, підготувати рану до закриття одним із методів пластичної хірургії.
Висновки. 1. Мікробіологічне дослідження дозволило встановити, що найбільшу частку мікробних угруповань склали стафілококи, мікрококи, коринебактерії, аеробні спороутворювальні бацили, стрептококи, ентеробактерії, псевдомонади, 3 загальною середньою колонізацією 7,38 lg КУО/г.

2. Використання вакуум-терапії до 6-ї доби дозволило знизити загальну щільність мікроорганізмів до $(4,19 \pm 0,45) \lg \mathrm{KУО/г,} \mathrm{що} \mathrm{було} \mathrm{достовір-}$ но нижче, ніж у контрольній групі $(5,88 \pm 0,66) \mathrm{lg}$ $\mathrm{KУO/г} \mathrm{(p<0,05).} \mathrm{Спостерігали} \mathrm{і} \mathrm{значне} \mathrm{зменшення}$ видового розмаїття мікроорганізмів у рані.

3. Під впливом вакуум-терапії хронічні ранові дефекти до 1,0 см в діаметрі епітелізувалися самостійно, а коли їх діаметр перевищував 1,0 cм проводили підготовку рани до пластичного закриття.

4. Вакуум-терапія ран у хворих на ССД позитивно впливає на перебіг ранового процесу і $\epsilon$ ефективним методом лікування, який дозволяє скоротити терміни стаціонарного лікування хворих на $(4,1 \pm 1,7)$ ліжко-дні. 


\section{СПИСОК ЛІТЕРАТУРИ}

1. Абаев Ю. К. Раны и раневая инфекция. Справочник хирурга / Ю. К. Абаев. - Ростов-на-Дону : Феникс, 2006. - 427 с. 2. Вакуум-інстиляційна терапія у хворих синдромом діабетичної стопи / О. М. Бєсєдін, Ю. Ю. Малюк, Л. І. Карпенко [та ін.] // Клінічна хірургія. - 2014. - № 11 (3). - С. 8-10.

3. Синдром диабетической стопы в клинической практике / В. Н. Оболенский, Т. В. Семенова, П. Ш. Леваль, А. А. Плотников // Русский мед. журнал. - 2010. - № 2. - С. 45-58.

4. Удовиченко О. В. Диабетическая стопа / О. В. Удовиченко, Н. М. Грекова. - М. : Практическая медицина, 2010. - 272 с. 5. Храмилин В. Н. Современные аспекты местного лечения хронических ран нижних конечностей у больных сахарным

\section{REFERENCES}

1. Abaev, Yu.K. (2006). Rany i ranevaya infektsiya. Spravochnik khirurga [Wounds and wound infection. Directory of a surgeon]. Rostov on the Don: Phenix [in Russian].

2. Beseedin, O.M., Malyuk,Yu.Yu., \& Karpenko, L.I. (2014). Vakuum-instiliatsiina terapiia u khvorykh syndromom diabetychnoi stopy [Vacuum-instillation therapy for patients with diabetic foot syndrome]. Klinichna khirurhiia - Clinical Surgery, 11 (3), 8-10 [in Ukrainian].

3. Obolenskyy, V.N., Semenova, T.V., Leval, P.S., \& Plotnikov, A.A. (2010). Sindrom diabeticheskoy stopy v klinicheskoy praktike [Diabetic foot syndrome in clinical practice]. Russkiy meditsinskiy zhurnal - Russian Med. Journal, 2, 45-58 [in Russian]. 4. Udovichenko, O.V., \& Grekova, N.M. (2010). Diabeticheskaya stopa [Diabetic foot]. Moscow: Prakticheskaya meditsina [in Russian]. диабетом / В. Н. Храмилин // Сахарный диабет. - 2005. - № 4. - C. $1-8$.

6. Poly (ADP-ribose) polymerase is activated in subjects at risc of developing type 2 diabetes and is associated with impaired wascular reactivity / C. Szabo, A. Zanchi, K. Komjati [et al.] // Circulation. - 2002. - Vol. 106. - P. 2680-2686.

7. Suzuki E. Prevalence and major risk factors of reduced flow volume in lower extremities with normal ankle-brechial index in Japanese patients with type 2 diabetes / E. Suzuki // Diabetes Care. - 2003. - P. 1443-1446.

8. The Foot in diabetes, 3d. Ed. A. J .M. Boulton, H. Connor, 41. P. Cavanagh (eds). J. Wiley \& Sons. Inc. - 2000. - 364 p.

5. Khramilin, V.N. (2005). Sovremennye aspekty mestnogo lecheniya khronicheskikh ran nizhnikh konechnostey u bolnykh sakharnym diabetom [Modern aspects of local treatment of chronic lower limb wounds in patients with diabetes mellitus]. Sakharnyy diabet - Diabetes Mellitus, 4, 1-8 [in Russian].

6. Szabo, C., Zanchi, A., \& Komjati, K. (2002). Poly (ADPribose) polymerase is activated in subjects at risc of developing type 2 diabetes and is associated with impaired wascular reactivity. Circulation, 106, 2680-2686.

7. Suzuki, E. (2003). Prevalence and major risk factors of reduced flow volume in lower extremities with normal anklebrechial index in Japanese patients with type 2 diabetes. Diabetes Care, 1443-1446.

8. Boulton, A.J.M., Connor, H. \& Cavanagh, P. (Eds.) (2000). The Foot in diabetes $3 d$. J. Wiley \& Sons. Inc.

\section{A. V. PAVLYSHYN}

I. Horbachevsky Ternopil State Medical University

\section{PECULIARITIES OF CHANGES IN THE SPECIFIC STRUCTURE OF MICROFLORA IN THE APPLICATION OF VACUUM THERAPY FOR CHRONIC WOUNDS IN PATIENTS WITH DIABETIC FOOT SYNDROME}

The aim of the work: to study the change in the quantitative and qualitative composition of the microflora in the application of vacuum therapy for chronic wounds in patients with diabetic foot syndrome.

Materials and Methods. Based on the examination and treatment of 122 patients with diabetes complicated by diabetic foot syndrome, who during 2013-2016 were hospitalized in the Clinic of General Surgery of I. Horbachevsky Ternopil State Medical University (Ternopil city municipal hospital Ambulance). Among the examined patients there were 79 (64.8 \%) men, and 43 (35.2\%) women, aged from 47 to 69 years. Patients with diabetes milder degree were 19 - mild, 76 - moderate, and 27 - heavy. The stage of compensation for diabetes is diagnosed in 43 patients (35.2 \%), subcompensation - in 62 (50.8\%), decompensation - in 17 (14\%) patients. Patients infected with neuropathic form were 48 (39.3\%), coronary-gangrenous - 74 (60.7\%). All patients underwent general clinical-laboratory and instrumental examination: objective examination, collecting complaints and history of the disease; changes of microhemodynamics lower extremities were studied cytological, microbiological and morphological studies were performed. The therapeutic effect of the vacuum was provided by the apparatus “AGAT-DNIPRO” (80-125 mm Hg). Quantitative and qualitative composition of the microflora was determined by bacteriological examination of the wound exudate on the day of admission, 3, 6, 9 and 14 days of treatment.

Results and Discussion. A microbiological study showed that in $42.6 \%$ there was a combination of 2-3 microorganisms, in $57.4 \%-$ 4-5. Most often, with chronic wounds, gram-positive microflora was sown (62.48 \%). Compared with the incidence, the colonization of wound defects significantly decreased ( $p<0.05-0.01$ ). The same trend was noted in the subsequent treatment periods. From the 6th day, the microbial contamination of chronic wounds decreased and amounted to (3.14 \pm 0.47$) \lg \mathrm{CFU} / \mathrm{g}$. On the 9th day total number of microorganisms was (3.36 \pm 0.37$) \mathrm{lg}$ CFU / g vs control group (1.94 \pm 0.12$) \lg$ CFU / g in the intervention group and 14 days of treatment of wounds did not stand out only aerobic bacilli. It was proved that the use of vacuum for treatment of chronic wounds reduces the quantity and species composition of microorganisms, which in turn reduces patient treatment on average (4.1 \pm 1.7$)$ days.

Key words: diabetes mellitus; diabetic foot syndrome; vacuum therapy. 
А. В. ПАВЛИШИН

ГВУз “Тернопольский государственный медицинский университет имени И. Я. Горбачевского Мз Украины”

\section{ОСОБЕННОСТИ ИЗМЕНЕНИЙ ВИДОВОГО СОСТАВА МИКРОФЛОРЫ ПРИ ИСПОЛЬЗОВАНИИ ВАКУУМНОЙ ТЕРАПИИ ХРОНИЧЕСКИХ РАН У БОЛЬНЫХ С СИНДРОМОМ СТОПЫ ДИАБЕТИКА}

Цель работы: изучить изменение количественного и качественного состава микрофлоры при применении вакуумной терапии хронических ран у больных синдромом стопы диабетика.

Материалы и методы. На основании обследования и лечения 122 больных сахарным диабетом с синдромом диабетической стопы, которые на протяжении 2013-2016 гг. находились на стационарном лечении в клинике общей хирургии ГВУЗ “Тернопольский государственный медицинский университет имени И. Я. Горбачевского МЗ Украины” (Тернопольской городской коммунальной больницы скорой помощи). Среди обследованных больных мужчин было 79 (64,8 \%), женщин 43 (35,2 \%) в возрасте от 47 до 69 лет. Больных СД легкой степени было 19, средней тяжести - 76, тяжелого - 27. Стадия компенсации СД диагностирована у 43 больных (35,2 \%), субкомпенсации - у 62 (50,8 \%), декомпенсации - у 17 (14 \%) пациентов. Больных с нейропатически-инфицированной формой (НИФ) ССД было 48 (39,3 \%), ишемически-гангренозной (ИГФ) - 74 (60,7 \%). Всем больным проводили общее клинико-лабораторное и инструментальное обследование: объективное обследование, сбор жалоб и анамнеза заболевания, изучали изменения микрогемодинамики нижних конечностей, проводили цитологические, микробиологические и морфологические исследования. Терапевтическое воздействие вакуума обеспечивали с помощью вакуум-аппарата “АГАТ-ДНЕПР” (80-125 мм рт. ст.). Количественный и качественный состав микрофлоры определяли с помощью бактериологического исследованиям раневого экссудата в день поступления, 3, 6, 9 и 14 сутки лечения. Результаты исследований и их обсуждения. Микробиологическое исследование показало, что в 42,6 \% наблюдалось сочетание 2-3 видов микроорганизмов, в 57,4\% - 4-5. Чаще при хронических ранах высевалась граммположительная микрофлора (62,48 \%). В сравнении с поступлением, достоверно уменьшалась колонизация раневых дефектов $(\mathrm{p}<0,05-0,01)$. Такая же тенденция отмечалась и в последующие сроки лечения. С 6 суток микробная контаминация хронических ран снизилась и составила $(3,14 \pm$ $0,47) \lg$ КОЕ /г. На 9-е сутки общее количество микроорганизмов составило $(3,36 \pm 0,37) \lg$ КОЕ /г в контрольной группе против $(1,94 \pm 0,12) \lg \mathrm{KOE} / \Gamma$ в основной группе, а с 14 дня лечения из ран не выделялись только аэробные бациллы. Доказано, что применение вакуума для лечения хронических ран уменьшает количественный и видовой состав микроорганизмов, что, в свою очередь, позволяет сократить стационарное лечение больных в среднем на $(4,1 \pm 1,7)$ койко-дня.

Ключевые слова: сахарный диабет; синдром стопы диабетика; вакуумная терапия. 